\title{
Change of the Asian dust source region deduced from the composition of anthropogenic radionuclides in surface soil in Mongolia
}

\author{
Y. Igarashi ${ }^{1}$, H. Fujiwara ${ }^{2}$, and D. Jugder ${ }^{3}$ \\ ${ }^{1}$ Atmospheric Environment and Applied Meteorology Research Department, Meteorological Research Institute, \\ 1-1 Nagamine, Tsukuba, Ibaraki 305-0052, Japan \\ ${ }^{2}$ Soil Environment Division, National Institute for Agro-Environmental Sciences, 3-1 Kannondai, Tsukuba, Ibaraki 305-8604, \\ Japan \\ ${ }^{3}$ Institute of Meteorology and Hydrology, Ulaanbaatar 46, Mongolia
}

Received: 6 September 2010 - Published in Atmos. Chem. Phys. Discuss.: 24 January 2011

Revised: 1 July 2011 - Accepted: 5 July 2011 - Published: 20 July 2011

\begin{abstract}
Recent climate change, especially during the 2000s, may be the primary reason for the expansion of the Asian dust source region. The change in the dust source region was investigated by examining anthropogenic radionuclides contained in surface soil samples from Mongolia. Surface soil was globally labeled by radioactive fallout from nuclear testing during the late 1950s and early 1960s, but there are no current direct sources for anthropogenic radionuclides in the air (before the Fukushima nuclear power plant accident in 2011). Radionuclides in the atmosphere are therefore carried mainly by wind-blown dust from surface soil, that is, aeolian dust. Asian dust carries traces of ${ }^{90} \mathrm{Sr},{ }^{137} \mathrm{Cs}$, and other anthropogenic radionuclides; the heaviest deposition occurs in spring and has been recorded in Japan since the early 1990s. The composition of anthropogenic radionuclides in atmospheric depositions would be affected by a change in the dust source. Previous studies of atmospheric deposition at long-term monitoring sites (e.g. in Tsukuba, Japan) have detected changes in the ${ }^{137} \mathrm{Cs} /{ }^{90} \mathrm{Sr}$ ratio and in the specific activity of the radionuclides. These changes in the composition of observed atmospheric depositions are supposed to reflect changes in the climatic conditions of the dust source region. To investigate this dust source change, we conducted a field survey of radionuclides $\left({ }^{90} \mathrm{Sr}\right.$ and $\left.{ }^{137} \mathrm{Cs}\right)$ in surface soil samples in September 2007 in the eastern and southern regions of Mongolia, where dust storms have occurred more frequently since 2000. The specific activities of both radionuclides as well as the ${ }^{137} \mathrm{Cs} /{ }^{90} \mathrm{Sr}$ ratio in the surface soil were well cor-
\end{abstract}

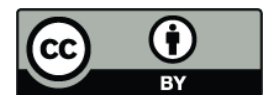

Correspondence to: Y. Igarashi (yigarash@mri-jma.go.jp) related with annual average precipitation in the Mongolian desert-steppe zone. Higher specific activities and a higher ${ }^{137} \mathrm{Cs} /{ }^{90} \mathrm{Sr}$ ratio were found in grassland regions that experienced greater precipitation. These findings suggest that the increased specific activities and the activity ratio detected in atmospheric depositions in Japan during years with frequent Asian dust transport events in the 2000s are a sign of grassland degradation.

\section{Introduction}

\subsection{Aeolian dust studies and available tracers}

Asian dust is the second largest aeolian dust source on Earth. Current estimates of global dust emissions range between 1000 and $3000 \mathrm{Tg} \mathrm{y}^{-1}$, and Saharan dust and Asian dust contribute about $50-70 \%$ and $10-25 \%$ of those amounts, respectively (Tanaka and Chiba, 2006; Tegen and Schepanski, 2009). Aeolian dust impacts the global climate by scattering and absorbing solar radiation, changing cloud properties, and affecting bio-geochemical cycles (e.g. Maher et al., 2010; Miller et al., 2004; Mikami et al., 2006; Mikami, 2007; Sassen et al., 2003). It also impacts human health through its effect on air quality in leeward regions (e.g. Chen et al., 2004; Ichinose et al., 2005; Kwon et al., 2002; Tamamura et al., 2007). Thus, research on Asian dust has not only scientific but also social implications. Although research on Asian dust has advanced rapidly in the past decade (Iwasaka, 2006; Iwasaka et al., 2009; Mikami et al., 2006; Osada, 2007; Shao and Dong, 2006), further research is necessary to gain a full understanding of temporal changes in dust

Published by Copernicus Publications on behalf of the European Geosciences Union. 
sources, features of transportation, and related controlling factors (Hara et al., 2006; Tian et al., 2007). In addition, the possibility of an eastward expansion of the source of Asian dust was suggested by Kurosaki and Mikami (2003) and Lim and Chun (2006) and later confirmed by Kim (2008). We have been investigating features of the continental and local dust sources using ${ }^{90} \mathrm{Sr}$ and ${ }^{137} \mathrm{Cs}$, which are anthropogenic radionuclides contained in the surface soil with half-lives of 30 years (Igarashi, 2004, 2009a, b; Igarashi et al., 2001, 2005, 2006, 2009; Fukuyama and Fujiwara, 2008; Fujiwara, 2010; Fujiwara et al., 2007).

To identify the source region of Asian dust, researchers have studied various tracers; ratios of stable isotopes such as ${ }^{87} \mathrm{Sr} /{ }^{86} \mathrm{Sr}$ and ${ }^{143} \mathrm{Nd} /{ }^{144} \mathrm{Nd}$ (Chen et al., 2007; Grousset et al., 2003; Kanayama et al., 2002; Lee et al., 2010; G. Li et al., 2009; Nakano et al., 2004), electron spin resonance and crystallinity of quartz (Nagashima et al., 2007; Ono et al., 1998; Sun et al., 2007), and various luminescences (Nagashima et al., 2010). Naturally occurring thorium was used in the observational studies of Hirose and Sugimura (1984), but anthropogenic radionuclides in the surface soil could also be used as chemical tracers. In addition to the ${ }^{90} \mathrm{Sr}$ and ${ }^{137} \mathrm{Cs}$ described here, plutonium isotopes are also candidates for use as tracers (Hirose et al., 2003, 2010).

\subsection{Anthropogenic radionuclides in surface soil as tracer for aeolian dust}

Global radioactive fallout caused by atmospheric nuclear explosions, especially during the late 1950 s to the early 1960s, resulted in widespread contamination of land and water (Aoyama et al., 2006). Surface soil all over the world still contains small amounts of these anthropogenic radionuclides. Given that there are no longer any major atmospheric contamination sources (prior to the Fukushima nuclear power plant accident in Japan in 2011), the main source of anthropogenic radionuclides in the air is wind-blown dust arising from surface soil. Because ${ }^{137} \mathrm{Cs}$ is tightly bound to soil particles, it has been widely used for land erosion studies (e.g. Ritchie and McHenry, 1990; Liu et al., 2008). The use of ${ }^{90} \mathrm{Sr}$ and ${ }^{137} \mathrm{Cs}$ as tracers for aeolian dust research, however, is a novel approach based on the long-term monitoring of atmospheric depositions (e.g. Igarashi et al., 2001). The inventories of ${ }^{90} \mathrm{Sr}$ and ${ }^{137} \mathrm{Cs}$ in the soil column are expected to be proportional to the amount of precipitation because their global fallout was deposited over the earth's surface mainly by rain and snow. In addition, because ${ }^{90} \mathrm{Sr}$ elutes faster than ${ }^{137} \mathrm{Cs}$ (e.g. Miller and Reittemeier, 1963; Forsberg and Strandmark, 2001) owing to their different distribution coefficients $\left(K_{\mathrm{d}}\right.$, Kamei-Ishikawa et al., $2008)$, the ${ }^{137} \mathrm{Cs} /{ }^{90} \mathrm{Sr}$ activity ratio in the surface soil directly reflects the amount of precipitation (Igarashi et al., 2001, 2006, 2009). Accordingly, the specific activities of the two radionuclides and the ${ }^{137} \mathrm{Cs} /{ }^{90} \mathrm{Sr}$ ratio in dust depositions can be interpreted as a proxy for climate conditions in the dust source region. If the source of aeolian dust extended to a region with substantially differing precipitation, the composition of the ${ }^{90} \mathrm{Sr}$ and ${ }^{137} \mathrm{Cs}$ in the uplifted dust would change accordingly. Distinctive ${ }^{90} \mathrm{Sr}$ and ${ }^{137} \mathrm{Cs}$ signatures in the soil could be used as tracers between source and receptor regions.

In the present paper, we describe the results of a 2007 survey of ${ }^{90} \mathrm{Sr}$ and ${ }^{137} \mathrm{Cs}$ levels in soil in Mongolia, one of the source regions of the recent Asian dust outbreak. We generated an average annual precipitation map of Mongolia based on long-term meteorological observations. We used the map to examine the relationship between annual precipitation and ${ }^{90} \mathrm{Sr}$ and ${ }^{137} \mathrm{Cs}$ composition at the sampling sites. We confirmed our hypothesis that the composition of the anthropogenic radionuclides in the surface soil is largely controlled by the precipitation rate in the dust source region. Finally, we use this evidence to argue that a change in the Asian dust source would be reflected by a variation in the composition of anthropogenic radionuclides in atmospheric depositions at downwind deposition sites. Hence, even without matching deposition signatures to source signatures, we can use longterm deposition monitoring to detect whether changes in the source region have occurred, even if we cannot precisely suggest where the new source regions are located.

The March 2011 accident at the Fukushima Dai-ichi nuclear power plant has understandably raised concerns about the potential health impacts of anthropogenic radionuclides. However, this paper addresses only the dust source shift. We do include a brief discussion of the negligible health impact of anthropogenic radionuclides contained in Asian dust in Appendix A.

\section{Sampling and analytical methods}

\subsection{Soil sampling and shipment}

Some of the authors conducted a local survey in eastern and southern Mongolia in autumn 2007. Sampling was conducted at 60 sites, which ranged from 700 to $1500 \mathrm{~m}$ in altitude; care was taken to avoid areas disturbed by human activities (Fig. 1). At each location, at spots as far from vehicular traffic and ruts as possible, an approximately $1-\mathrm{kg}$ sample of undisturbed surface soil was collected to a depth of $5 \mathrm{~cm}$ by using a core sampler. The sample was packed into a plastic bag without eliminating stones, pebbles, grasses, or roots. The soil samples were later repacked into heat-resistant bags, and the bags were packaged in tightly covered containers to avoid any damage and were airlifted from Mongolia to Japan. An autoclave treatment, which is required by Japanese regulations, was performed at the Plant Protection Station at the Narita Airport in Japan. After treatment, the samples were transported to the laboratory at the Meteorological Research Institute (MRI), Tsukuba, Japan. 


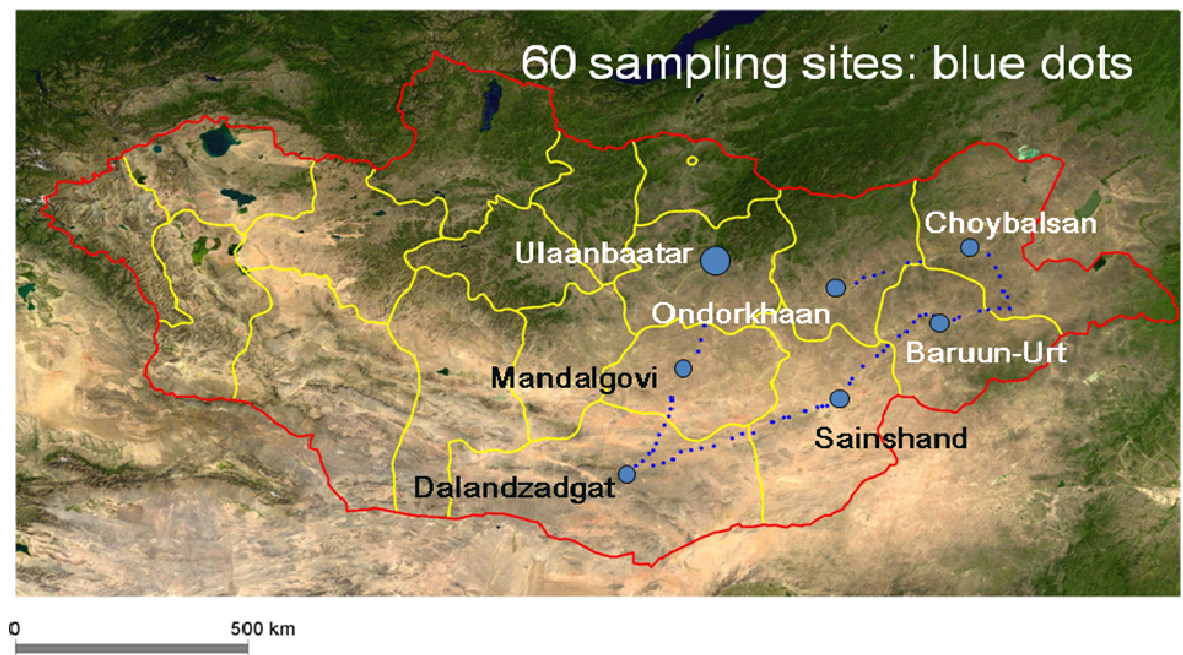

Fig. 1. Sampling sites of a survey of anthropogenic radionuclides in surface soil in Mongolia in the fall of 2007 . Red and yellow lines indicate Mongolian and aimag (prefecture) borders, respectively. Small blue dots are the sampling sites, and the large ones are cities and towns, which were avoided for sampling. The background land color image is from TNT Global Data Sets (MicroImages, Inc., Nebraska, USA).

\subsection{Analytical procedures for anthropogenic radionuclides}

Once in the laboratory, the samples were immediately airdried at room temperature. Stones, pebbles, grasses, and roots were carefully removed by hand. After the samples were dried, particle size distribution was measured with screens on a mechanical shaking apparatus to obtain the analytical sample. The fraction that passed through a $53-\mu \mathrm{m}$ mesh (nominal) was then subjected to radioactivity analysis because this fraction was regarded as capable of being suspended and transported by strong wind. The screening procedure was the same as that applied to soil samples collected in areas neighboring the MRI in Tsukuba. Details of the analytical procedures are given in Otsuji-Hatori et al. (1996). After being packed into a uniform plastic container, each sample was subjected to $\gamma$-ray measurement using a Ge semiconductor detector (EG\&G Ortec/Eurisys) for ${ }^{137} \mathrm{Cs}$. After the $\gamma$-ray measurement, ${ }^{90} \mathrm{Sr}$ was concentrated using radiochemical separation. The procedure involved several precipitation separation steps, including the fuming nitric acid method and others. Finally, the ${ }^{90} \mathrm{Sr}$ was isolated and fixed as strontium carbonate on filter paper in a metal dish. The samples were left for a few weeks so that ${ }^{90} \mathrm{Sr}$ and ${ }^{90} \mathrm{Y}$ reach radioequilibrium, and the purified ${ }^{90} \mathrm{Sr}$ source was then measured with a low-background $2 \pi$-gas flow $\beta$-counter (Tennelec). Quality management of the analysis was achieved using a reference sample of fallout that was previously prepared by the MRI (Otsuji-Hatori et al., 1996).

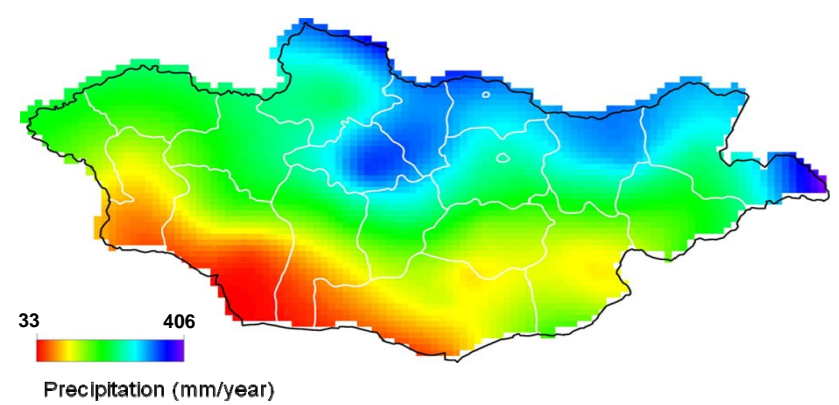

Fig. 2. Raster map of interpolated annual average precipitation in Mongolia derived from the precipitation records of 24 meteorological observatories during 1950-2007 using the minimum curvature method (see text for a more detailed explanation).

\subsection{Mean annual precipitation in Mongolia}

To investigate the relationship between ${ }^{90} \mathrm{Sr}$ and ${ }^{137} \mathrm{Cs}$ in the soil and precipitation at the sampling sites, a gridded map of the precipitation of Mongolia was created (Fig. 2) based on the annual precipitation data collected by the Institute of Meteorology and Hydrology of Mongolia for 25 sites from 1950 to 2007. The data were compared to mean annual precipitation data for the same sites from 1961 to 1990 published by the Japan Meteorological Business Support Center (JMBSC) to assess consistency. The data for Ulgii $\left(49.0^{\circ} \mathrm{N}, 90.0^{\circ} \mathrm{E}\right.$; WMO\# 44214) were removed because of inconsistencies (the present data was shown three times as the JMBSC data). So, the map uses the data from 24 sites. Precipitation data for areas outside Mongolia were also necessary to estimate the distribution of precipitation at the 

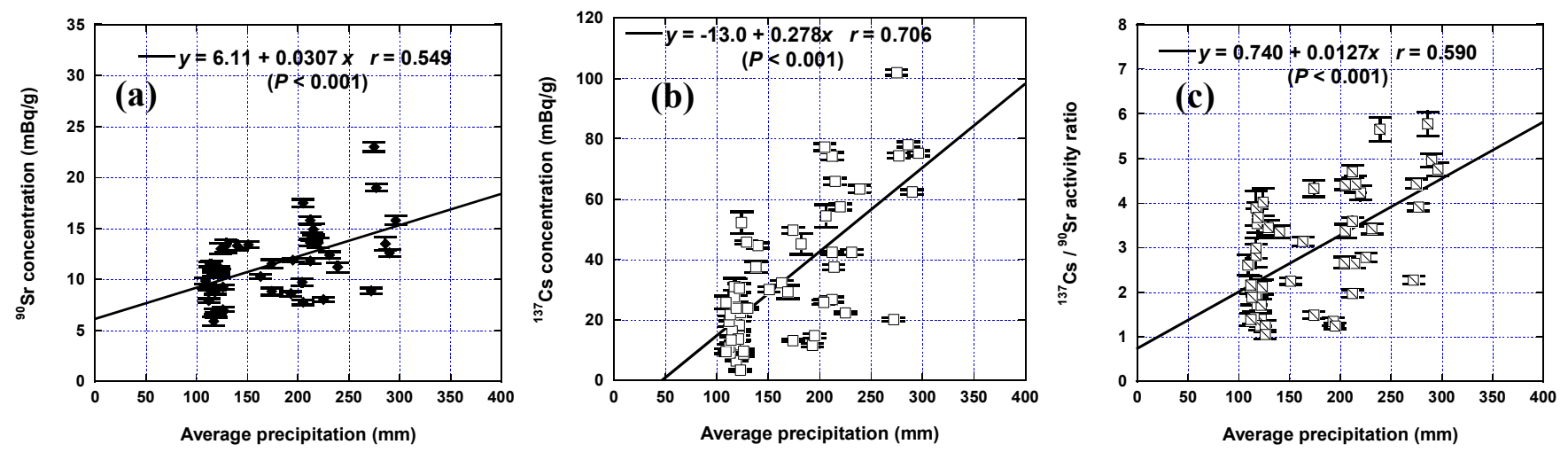

Fig. 3. Relationship between the specific activities of (a) ${ }^{90} \mathrm{Sr}$ and (b) ${ }^{137} \mathrm{Cs}$ in Mongolian surface soil samples and estimated average annual precipitation data at the sampling sites. (c) Relationship between the ${ }^{137} \mathrm{Cs} /{ }^{90} \mathrm{Sr}$ activity ratio and precipitation. The error bars indicate counting statistics of $1 \sigma$ in the measurement.

Table 1. Specific activities (dry weight basis) for anthropogenic radionuclides and their activity ratio in Mongolian surface soil and comparison with related data of surface soils collected in Taklimakan and Tsukuba (other than Mongolian soil, the data cited are based on Igarashi et al., 2005, 2009). All data are decay-corrected as of the time of sample collection in the fall of 2007.

\begin{tabular}{cccc}
\hline Sample & $\begin{array}{c}{ }^{137} \mathrm{Cs}\left(\mathrm{mBq} \mathrm{g}^{-1}\right) \\
\text { Specific activity }\end{array}$ & $\begin{array}{c}{ }^{90} \mathrm{Sr}\left(\mathrm{mBq} \mathrm{g}^{-1}\right) \\
\text { Specific activity }\end{array}$ & $\begin{array}{c}{ }^{137} \mathrm{Cs} /{ }^{90} \mathrm{Sr} \\
\text { ratio }\end{array}$ \\
\hline Mongolian soil $\left(n=57\right.$ for ${ }^{137} \mathrm{Cs} ; n=36$ for $\left.{ }^{90} \mathrm{Sr}\right)$ & & \\
Max. & 102 & 23.0 & 5.8 \\
Min. & 3.29 & 5.9 & 1.2 \\
Median & 26.2 & 11.7 & 3.4 \\
\hline Taklimakan dust $(n=1)$ & $6.12 \pm 1.20$ & $1.52 \pm 0.22$ & 4.0 \\
\hline Taklimakan soil $(n=6)$ & & & \\
Max. & 22.3 & 7.82 & 3.6 \\
Min. & 3.38 & 1.47 & 1.7 \\
Median & 11.3 & 4.52 & 2.2 \\
\hline Tsukuba soil $(n=9)$ & & & 10.4 \\
Max. & 13.3 & 2.80 & 5.1 \\
Min. & 3.27 & 0.66 & 7.9 \\
Median & 11.9 & 1.47 & 6.0 \\
\hline Monthly deposition sample at MRI ${ }^{\mathrm{a}}$ during springs in the $1990 \mathrm{~s}$ and $2000 \mathrm{~s}(\mathrm{~Bq} \mathrm{~g}-1)(n=45)$ \\
Max. \\
Min. & 21.2 & 4.73 & 0.8 \\
Median & 3.09 & 1.24 & 2.6 \\
\hline
\end{tabular}

a Meteorological Research Institute, Tsukuba, Japan

boundary. The precipitation data of neighboring countries, such as China and Russia, were taken from the report of the World Meteorological Organization (WMO, 2009). The grid data were generated by the minimum curvature method using interpolation and extrapolation techniques (Fujiwara et al., 2007) on a grid with cell size of $20 \times 20 \mathrm{~km}$.

\section{Results and discussion}

\section{$3.1{ }^{90} \mathrm{Sr}$ and ${ }^{137} \mathrm{Cs}$ in Mongolian surface soil}

The ${ }^{90} \mathrm{Sr}$ and ${ }^{137} \mathrm{Cs}$ specific activities and the ${ }^{137} \mathrm{Cs} /{ }^{90} \mathrm{Sr}$ ratio of the Mongolian soil are summarized in Table 1 together with previously published values for surface soil and atmospheric total (wet + dry) deposition (Igarashi et al., 2005, 2009). The data were decay-corrected as of fall 2007, the time the soil samples were collected in Mongolia. The 
median levels of specific activity of ${ }^{90} \mathrm{Sr}$ and ${ }^{137} \mathrm{Cs}$ in the Mongolian soil were higher than those of Tsukuba, about 8 times the level for ${ }^{90} \mathrm{Sr}$ and 2 times the level for ${ }^{137} \mathrm{Cs}$. In addition, the maximum values for both radionuclides from Mongolia were more than 5 times those of Tsukuba. The median ${ }^{137} \mathrm{Cs} /{ }^{90} \mathrm{Sr}$ ratio of the Mongolian soil was about half that of the Tsukuba soil. Liu et al. (2008) investigated ${ }^{137} \mathrm{Cs}$ in Mongolian soil to study wind erosion rates. Although their data and analyses were different than ours (they used a 2-mm sieve), their data range (about $5-70 \mathrm{mBqg}^{-1}$ ) is consistent with ours. The range was also in agreement with the data of Fujiwara et al. (2007) for Inner Mongolia.

In Tsukuba, the soil samples were collected in rice paddies, vegetable fields, and similar locations where the fallout anthropogenic radionuclides in soil are diluted by plowing, whereas the surface soil sampled in Mongolia had not been disturbed by cultivation. In addition, the low amount of precipitation and freezing in the winter climate in the desertsteppe zone should also help prevent the diffusion and elution of the anthropogenic radionuclides into the deeper soil column. Although the fallout amount of anthropogenic radioactivity in Mongolia was less than half of that in Japan (Aoyama et al., 2006), ${ }^{137} \mathrm{Cs}$ in Mongolia seems to be concentrated almost exclusively in the surface and exhibited elevated specific activity, which was also found by Fujiwara et al. (2007) and Liu et al. (2008) in Inner Mongolia and Mongolia, respectively.

Accordingly, it is reasonable to assume that depositions of aeolian dust in Japan with elevated ${ }^{90} \mathrm{Sr}$ and ${ }^{137} \mathrm{Cs}$ specific activities derive from continental grassland surface soil (Akata et al., 2007; Fujiwara et al., 2007). Mongolian surface soils have higher specific activities of both radionuclides and a higher ${ }^{137} \mathrm{Cs} /{ }^{90} \mathrm{Sr}$ ratio than Taklimakan Desert soil and dust. The difference in precipitation could be the reason. The Taklimakan Desert receives less than $100 \mathrm{~mm} \mathrm{yr}^{-1}$ of precipitation (Yuan and Li, 1999), and the precipitation in the middle of the desert is estimated to be less than $20 \mathrm{~mm} \mathrm{yr}^{-1}$ (Xuan et al., 2004), whereas annual precipitation is much greater in Mongolia (see Sect. 3.2). Thus, the amount of global fallout and vertical fractionation between ${ }^{90} \mathrm{Sr}$ and ${ }^{137} \mathrm{Cs}$ has been suppressed in the Taklimakan Desert.

\subsection{Mean annual precipitation map of Mongolia}

Figure 2 shows clear contrasts between the forest-steppe region in northern Mongolia, which has a greater amount of precipitation, and the so-called Gobi Desert in southern Mongolia, which has a lower amount of precipitation. The mean annual precipitation at the 24 Mongolian local meteorological observatories over approximately 50 years ranged from about 150 to $300 \mathrm{~mm} \mathrm{yr}^{-1}$. The relationship between the specific activity of each radionuclide and the estimated precipitation at each sampling site is plotted in Fig. $3 a$ and $b$, and the relationship between the ratio of both activities and precipitation is shown in Fig. 3c. Precipitation at the sampling sites ranges from about 100 to $300 \mathrm{~mm} \mathrm{yr}^{-1}$, indicating that most of the sampling sites are in the dessert-steppe zone. Although the precipitation range was narrow (only $200 \mathrm{~mm} \mathrm{yr}^{-1}$ ), there was a statistically significant positive correlation with specific activity for both radionuclides $(P<0.001)$. The areas with higher specific activity tend to be grassland with shrubs, and conversely, shrubs are scarce in areas with lower specific activity. ${ }^{90} \mathrm{Sr}$ in the soil column elutes faster than ${ }^{137}$ Cs (e.g. Forsberg and Strandmark, 2001), and the elution of ${ }^{90} \mathrm{Sr}$ in the soil would be affected not only by precipitation but also by variations in soil characteristics, such as organic matter content and ion exchange capacity. ${ }^{137} \mathrm{Cs}$ and estimated precipitation were more strongly correlated $(r=0.706)$ than were ${ }^{90} \mathrm{Sr}$ and precipitation $(r=0.549)$, which seemed consistent with the $K_{\mathrm{d}}$ values for each radionuclide. The ${ }^{137} \mathrm{Cs} /{ }^{90} \mathrm{Sr}$ activity ratio was also well correlated with precipitation (Fig. 3c). In other words, in the continental grasslands with relatively greater amounts of rain (the "moist-steppe" region), the specific activities of both radionuclides and the ${ }^{137} \mathrm{Cs} /{ }^{90} \mathrm{Sr}$ activity ratios of the surface soil are higher.

\subsection{Cross plotting ${ }^{90} \mathrm{Sr}$ and ${ }^{137} \mathrm{Cs}$ for various samples}

To investigate the effect of the desert-steppe zone surface soil dust from the Asian continent on the atmospheric depositions observed in Tsukuba, we created a cross plot of the anthropogenic radionuclides for Mongolian soil, Taklimakan soil and dust, Tsukuba soil, and atmospheric depositions in Tsukuba (Fig. 4). Figure 4 can be considered as an analogue to plots widely used in stable isotope studies, for example, $\varepsilon \mathrm{Nd}$ over ${ }^{87} \mathrm{Sr} /{ }^{86} \mathrm{Sr}$ (e.g. Nakai et al., 1993; Nakano et al., 2004; Lee et al., 2010). There was a significant positive linear correlation $(r=0.867)$ between ${ }^{137} \mathrm{Cs}$ content and the ${ }^{137} \mathrm{Cs} /{ }^{90} \mathrm{Sr}$ ratio in Mongolian soil samples because both of them are controlled by the amount of precipitation, as Igarashi et al. (2009) assumed. This linear curve appears as if it was produced by the mixing of two end members (a mixing line), but the linear relationship also could have been a result of simple bio-geochemical processes in the region. The Taklimakan soil samples also exhibit a linear correlation between ${ }^{137} \mathrm{Cs}$ activity and the ${ }^{137} \mathrm{Cs} /{ }^{90} \mathrm{Sr}$ activity ratio with a similar slope to that of the Mongolian soil but with a higher intercept. Although the higher intercept of the Taklimakan soil is not fully understood, the similarity between the slopes of the ${ }^{137} \mathrm{Cs}-{ }^{137} \mathrm{Cs} /{ }^{90} \mathrm{Sr}$ correlations for the Taklimakan and Mongolian soils implies that the soil in the wide arid and semiarid areas of North China, Inner Mongolia, and Mongolia will show the similar ${ }^{137} \mathrm{Cs}-{ }^{137} \mathrm{Cs} /{ }^{90} \mathrm{Sr}$ correlation as that of the Taklimakan and Mongolian soils. The Taklimakan dust had a higher ${ }^{137} \mathrm{Cs} /{ }^{90} \mathrm{Sr}$ ratio $(4.0 \pm 0.99)$ than the Taklimakan soil, possibly because of the relatively large analytical error or the grain-size effect (see Sect. 3.4 and Appendix B). Unlike the Asian continental soil, the Tsukuba soil samples are characterized by low ${ }^{137} \mathrm{Cs}$ specific activity 


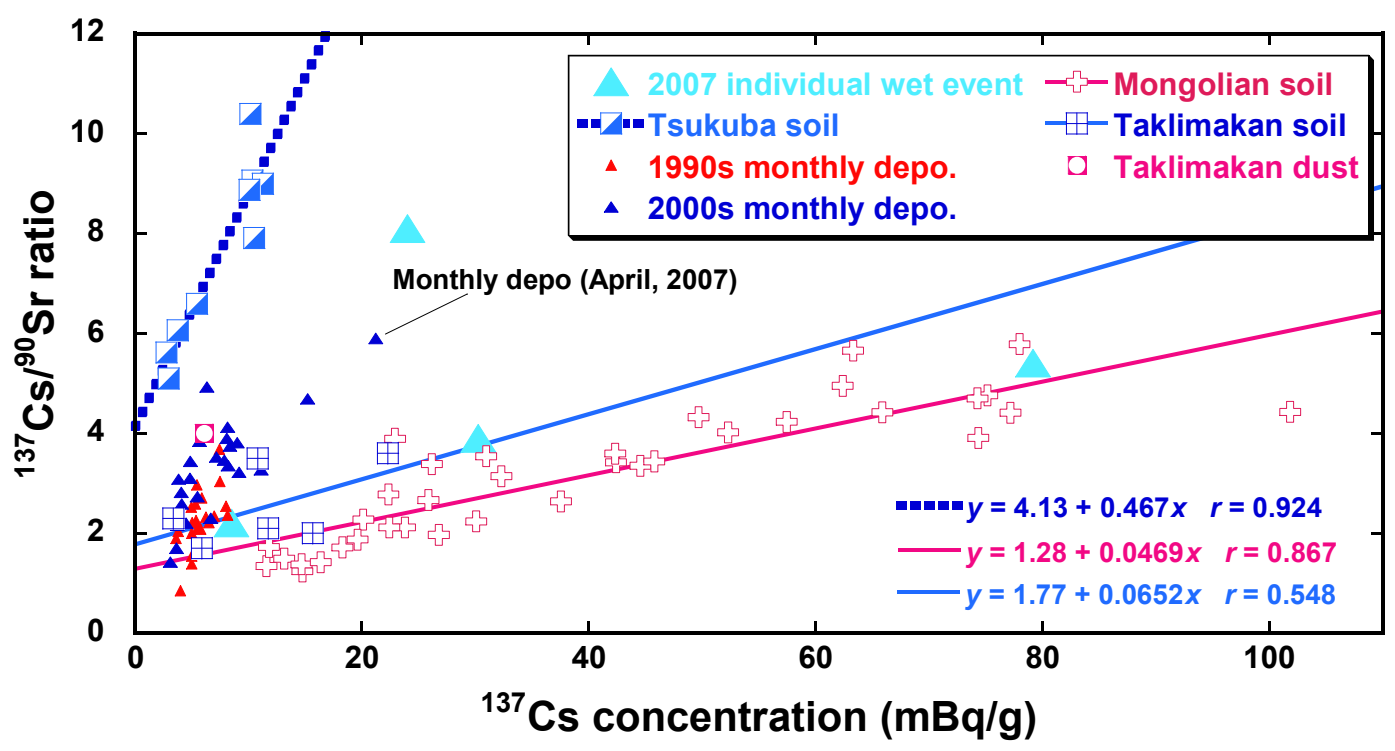

Fig. 4. A cross plot of Mongolian surface soil, Tsukuba surface soil, Taklimakan surface soil and dust, and atmospheric deposition (monthly and event samples) during spring (March, April, and May) in Tsukuba based on the relationship between ${ }^{137} \mathrm{Cs}$ specific activity (mBq $\mathrm{g}^{-1}$ ) and the ${ }^{137} \mathrm{Cs} /{ }^{90} \mathrm{Sr}$ activity ratio. The monthly deposition is total (wet + dry) deposition, and single wet depositions were collected during the spring of 2007 (from Igarashi et al., 2009). Taklimakan and Tsukuba soil data are based on Igarashi et al. (2005). Fitting curves are individually drawn for Mongolian, Tsukuba, and Taklimakan soils. All data are decay-corrected as of the time of sample collection in the fall of 2007.

and a high ${ }^{137} \mathrm{Cs} /{ }^{90} \mathrm{Sr}$ activity ratio. The atmospheric deposition data are dispersed between the Asian continental soil and the Tsukuba soil clusters, which suggest that atmospheric deposition in Tsukuba could be created by mixing the continental and local dust components as end members. Local dust can be raised into the air by small-scale swirls or gusts, which occur when cold fronts are passing. Frontal systems are composed of several sub-scale fronts, and precipitation is not homogeneous but patchy. Because agricultural activities occur during the spring in Japan, the conditions in the fields in the Kanto area, where Tsukuba is located, favor soil particle suspension (the fields are bare plowed surfaces). Especially during the early stage of a rain event, local dust could be sampled along with the rain. The interpretation of the deposition is thereby more complicated. Hayasaki et al. (2011) showed a typical example of this type of situation.

The spring atmospheric deposition data for the 1990s are distributed along a narrow range for ${ }^{137} \mathrm{Cs}$ specific activity, which may be a result of mixing of Tsukuba and continental soils from a relatively dry climatic zone because the latter have low ${ }^{137} \mathrm{Cs}$ specific activity as well as a low ${ }^{137} \mathrm{Cs} /{ }^{90} \mathrm{Sr}$ activity ratio. In contrast, the spring atmospheric deposition data for the 2000s shifted toward those of continental soils from the relatively humid climatic zone, which have high ${ }^{137} \mathrm{Cs}$ specific activity as well as a high ${ }^{137} \mathrm{Cs} /{ }^{90} \mathrm{Sr}$ activity ratio, indicating the atmospheric depositions in the 2000s are created by mixing the Tsukuba and continental soils (likely to be two components from relatively dry and relatively hu- mid zones). A frequency distribution of the ${ }^{137} \mathrm{Cs} /{ }^{90} \mathrm{Sr}$ activity ratios and the decade averages of the ratios from the spring atmospheric deposition in the 1990s and the 2000s are shown in Fig. 5.

Three of the four single precipitation events (wet only samples) during spring 2007 exhibited relatively high ${ }^{137} \mathrm{Cs}$ specific activity $\left(25-80 \mathrm{mBq} \mathrm{g}^{-1}\right)$, which could reflect a major contribution from a relatively humid continental source. One of the data points is even located at the high end of the Mongolian and Taklimakan soil curves. The dust deposited during the event displayed the characteristics of grassland surface soil, which is consistent with the findings of a backward trajectory analysis of the air mass (Igarashi et al., 2009). The air parcel that brought this precipitation was considered to have developed in northern China and Mongolia (Igarashi et al., 2009), which is evidence that the recent Asian dust outbreak over the continent is related to surface degradation (desertification).

Higher levels of ${ }^{90} \mathrm{Sr}$ and ${ }^{137} \mathrm{Cs}$ were found in the atmospheric depositions in Japan in the years of the 2000s when frequent Asian dust events occurred. The deposition was most pronounced during March 2002, when ${ }^{90} \mathrm{Sr}$ and ${ }^{137} \mathrm{Cs}$ were observed throughout Japan (Fujiwara et al., 2007; Fujiwara, 2010; Igarashi et al., 2006; Igarashi, 2009b). At that time, deposition was several times the normal levels, especially in areas along the Sea of Japan and in northern Japan. Some of these events were tracked back to source areas in northern China and Mongolia (Akata et al., 2007; Fujiwara 


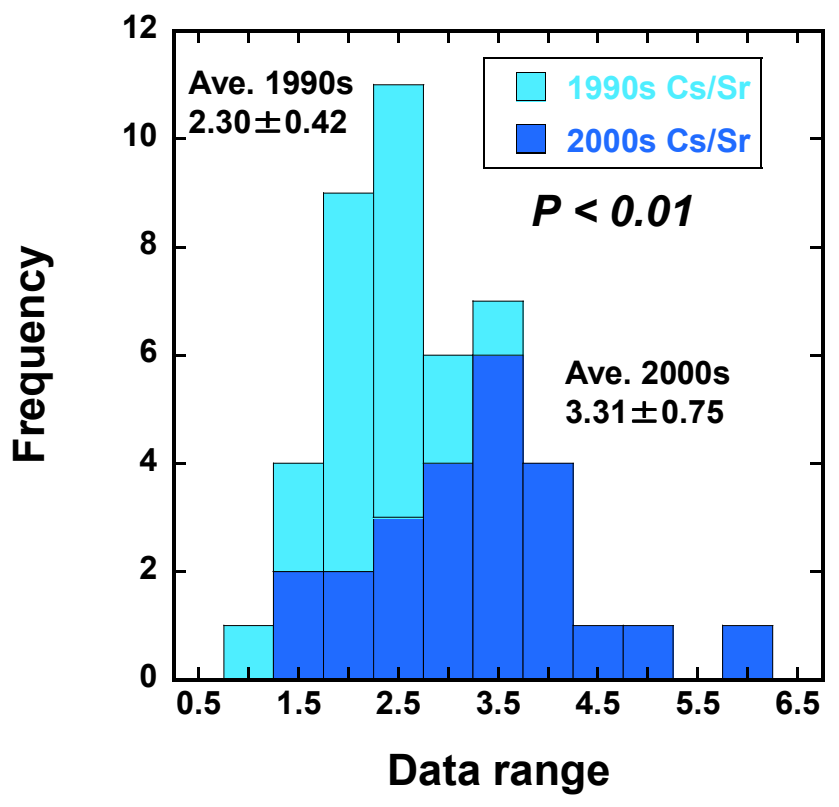

Fig. 5. Frequency distribution of the ${ }^{137} \mathrm{Cs} /{ }^{90} \mathrm{Sr}$ activity ratio in the monthly atmospheric depositions at the MRI in Tsukuba during spring in the 1990s and 2000s. The decade averages of the two data sets are significantly different $(P<0.01)$.

et al., 2007). The higher specific activities and activity ratio in the atmospheric depositions found in areas along the Sea of Japan and in northern Japan in March 2002 could have been a result of contributions from the relatively humid grassland soils of Mongolia, Inner Mongolia, and northern China. The climatic-biological system should, in principle, be similar in the arid and semiarid regions across East Asia. Semi-desert shrubs and grasslands are distributed throughout southern and eastern Mongolia, in the middle of Inner Mongolia, and in northeastern China (see Fig. 6 in Fujiwara et al., 2007, Fig. 1b in Kurosaki and Mikami, 2007, and Fig. 1 in Lin et al., 2006). According to Tian et al. (2007), the dust storms observed at stations in Inner Mongolia and its vicinity have a stronger influence on Asian dust observation in Japan (by Japan Meteorological Agency) than do other dust source regions in northern China. The soil degradation in northeastern China, Inner Mongolia, and eastern Mongolia would therefore have the greatest effect on Japan as compared to other western dust source regions.

\subsection{Grain-size effect on the composition of anthropogenic radionuclides}

Because the particle size distributions are different for soil samples and deposition samples and because anthropogenic radionuclides are surface adsorbent, the above-mentioned comparisons do have limitations, as has been discussed for the comparable case of grain size and stable isotopes (e.g. Chen et al., 2007). All soil samples in this study were passed through a 53- $\mu \mathrm{m}$ mesh screen. The local dust, which is captured by an open-surface sampler, contains larger particles, up to several hundred micrometers in size. The present analytical sieving process seems adequate to extract the fraction suspended by wind from local soil samples. In the case of the Mongolian soil, only dust particles less than $10 \mu \mathrm{m}$ in diameter are transported thousands of kilometers in the air over the Asian continent and the Sea of Japan. Sieving with a finer mesh is needed to achieve higher precision in the measurements of specific activity. However, finer soil particles will exhibit higher specific activity not only for ${ }^{137} \mathrm{Cs}$ (Tsukada et al., 2008) but also for ${ }^{90} \mathrm{Sr}$, which is controlled by the total particle surface area over the mass; thus, it is unlikely that there would be a substantial change in the ${ }^{137} \mathrm{Cs} /{ }^{90} \mathrm{Sr}$ ratio. Therefore, the present conclusion is also not likely to change substantially. Nevertheless, we cannot totally reject the possibility and have begun a radiochemical analysis of the finer sized fraction of the dust samples. Although the number of the samples is currently limited, preliminary results show that the ${ }^{137} \mathrm{Cs} /{ }^{90} \mathrm{Sr}$ ratios for dust particles of less than $10 \mu \mathrm{m}$ are similar to those of the 53- $\mu \mathrm{m}$ fraction (see Appendix $\mathrm{B}$ for a more detailed description of the preliminary results).

\subsection{The Asian dust source change since the early 2000s}

Xuan et al. (2004) defined the Asian dust source region as having two parts or systems: the Mongolian Plateau and the Tarim Basin. Although this definition seems common among meteorological researchers (e.g. Huang et al., 2008; Iwasaka et al., 1983; Qian et al., 2002; Shao and Dong, 2006; Sun et al., 2001; Tegen and Schepanski, 2009), this classification may be too coarse geographically. In the present manuscript, we have focused on whether there has been a change in the dust source toward the desert-steppe zones (especially for grasslands) but have not attempted to identify the precise source region.

As a general trend, the annual incidence of dust events over China decreased from the 1960s to the late 1990s (e.g. Hara et al., 2006; Zhang et al., 2003; Wang et al., 2008). This decrease may have been due to declining dust storm activity in the Tarim Basin. Dust events then increased after 2000, possibly as a result of the increasing dust storm activity in the Mongolian Plateau and adjacent source regions. This dust source change has been documented in previous reports, such as Kurosaki and Mikami (2003), Lim and Chun (2006), and Kim (2008). Kurosaki and Mikami (2003) reported that the outbreak of dust storms on the Asian continent had dramatically increased in areas other than the conventional dust source regions during 2000-2002. This geographical expansion seems attributable to the desertification of the less eroded grassland regions. The extent of temporal desertification over the Asian continent has been studied using satellite images and the normalized difference vegetation index (NDVI). Zou and Zhai (2004) noted for the first time 
the relationship between vegetation coverage and spring dust outbreaks over northern China based on an NDVI analysis. Lin et al. (2006) reported that, "desert areas were expanded from 2000 to 2002, were shrunk in 2003, and were expanded from 2003 to 2005 again. The hot spot areas of desertification are mainly distributed over southeastern Mongolia and eastern Inner-Mongolia." In the case of a severe drought, the NDVI values decrease by $19 \%$ in taiga, $30-55 \%$ in foreststeppe areas, $55-78 \%$ in steppe areas, and more than $64 \%$ in desert-steppe areas as compared with the corresponding values in very wet years (Bayasgalan, 2005). Recently, Sugimoto et al. (2010) considered the role of vegetation cover on dust emissions from the Mongolian Gobi region during spring 2007. They concluded that the growth of grass had significantly suppressed dust emissions there.

A major concern is the question of what is responsible for the change in the dust source toward grassland. Is it human impacts (over-grazing, over-reclamation, land misuse, etc.), climatic changes, or some combination of both? Zhang et al. (2003) stressed that "meteorology and climate have had a greater influence on the Asian dust emissions and associated Asian dust storm occurrences than desertification." Ding et al. (2005), Han et al. (2008), Hara et al. (2006), Wang et al. (2008), and others have argued that the variation in dust storm occurrence is related to the change in large-scale atmospheric circulation. Kurosaki and Mikami (2005) found the suppression effect of snow cover on dust emissions. On the other hand, Wang et al. (2006) conducted a comprehensive analysis of "proxies for human activity to evaluate the key contributors to desertification" for the northeastern part of Inner Mongolia, where the desertsteppe occurs. They concluded that human activities were not the primary driving force of desertification in the region. Because the Mongolian grassland is rather fragile (Xuan et al., 2004), the grass cover may be susceptible to small reductions in precipitation. Narabayar (2009) found that the area of arid regions has increased by $3.4 \%$ during the past decade and that $78.2 \%$ of the all land has been somehow degraded. He ascribed such wide degradation in Mongolia to warming without any increase in precipitation. A recent assessment in Mongolia indicates that the percentage of desert zone (net primary productivity $<60 \mathrm{Ch} \mathrm{m}^{-2}$ ) tends to expand to the north (MARCC2009, 2010). According to Xuan et al. (2004), simulated dust emission rates increase from north to south across Mongolia by 5 orders of magnitude, with the maximum appearing southwest of the Gobi area. Xuan et al. (2004) stated that "The poor alpine ecosystem of Mongolia is fragile. In the 1950s, the exploration [exploitation?] of dry grasslands for farming near Ulan Bator resulted in serious soil erosion and desertification."

Consequently, the scenario that appears to best describe the dust source change, and which would be consistent with the conclusion of Fujiwara et al. (2007), is as follows: a slight reduction in precipitation in the desert-steppe zone caused the widespread increase in fresh bare surfaces. These bare surfaces were exposed to strong winds, which resulted in the dust storm outbreaks during the 2000s. This scenario is further supported by J. Li et al. (2009), who discuss the recent weakening of the summer Asian monsoon and refer to the increasing "northern drought and southern flood" moisture pattern (Yu et al., 2004). A change in the humidity distribution over the Asian continent would be of fundamental importance to the pattern and characteristics of outbreaks of dust storms.

\section{Conclusions}

This is the first report that provides a detailed discussion of the Asian dust outbreak, with an extensive presentation of data on anthropogenic radionuclides in continental surface soil. It was revealed that, in the East Asian desert-steppe zone, levels of ${ }^{90} \mathrm{Sr}$ and ${ }^{137} \mathrm{Cs}$ in the surface soil had a notable correlation with precipitation. Their specific activities as well as the ${ }^{137} \mathrm{Cs} /{ }^{90} \mathrm{Sr}$ ratio were consequently shown to be useful as a proxy for climatic conditions in the dust source region, for which conventional isotope tracers were of almost no use. The Asian dust source regions are spreading eastward and northward from the conventional source as a result of the degradation of the relatively moist zone (grasslands) in years that have experienced frequent Asian dust events (during the 2000s). The major controlling factor may not be direct anthropogenic activities but possibly climate change, especially slightly reduced precipitation, which has amplified surface degradation due to the fragility of the ecosystem. Dust particles less than $10 \mu \mathrm{m}$ in size are most likely actually transported thousands of kilometers in the air, and a radiochemical analysis of this smaller sized fraction in source soils is a task for further verification of the present study, although we do not expect any major change in the conclusions. Also, future cross-over studies with other tracer techniques could offer more insights into temporal changes in the source region of Asian dust and related factors.

\section{Appendix A}

\section{A1 No direct link to past nuclear tests}

There are significant social concerns over anthropogenic radionuclides in the atmosphere, and some people worry that Asian dust may convey contaminants as a result of past Chinese nuclear tests in the Taklimakan Desert. The data in this study do not show that Asian dust conveys direct contamination from those nuclear tests, but the dust does sometimes carry ordinary continental grassland soil. Although relatively high levels of radionuclides are not frequently detected in the air by general radioactivity monitoring in the absence of nuclear accidents or serious contamination, it should be noted that the Asian dust phenomena can generate enhanced 
atmospheric radioactivity. For example, radionuclides conveyed by Asian dust are most likely the reason that Hirose et al. (2010) observed high specific activity of Pu isotopes in atmospheric depositions in several springs with frequent Asian dust events during the 2000s in Japan.

Researchers in France (Menut et al., 2009; Masson et al., 2010) needed to solve a similar problem for transported Saharan dust because it also contains a trace but detectable amount of ${ }^{137} \mathrm{Cs}$ and other radionuclides. ${ }^{137} \mathrm{Cs}$ contamination detected in France during a Saharan dust event was suspected to be the result of leakage from past nuclear test sites in French Saharan territory (Danesi et al., 2008). Igarashi et al. (2005) pointed out that close-in fallout from atmospheric nuclear explosions should have been an insignificant source of surface contamination of ${ }^{90} \mathrm{Sr}$ and ${ }^{137} \mathrm{Cs}$ around the test sites, thus negligible in aeolian dust transport; and French researchers drew similar conclusions (Menut et al., 2009; Masson et al., 2010). Only $0.7 \%$ of the Saharan dust was ascribed to the test area, accounting for only a small percentage of the atmospheric ${ }^{137} \mathrm{Cs}$ peak concentrations recorded in France during the transport event (Menut et al., 2009). These results indicate that the Saharan dust episode might have a common background with the present Asian dust case - degradation of grassland where the surface serves as a reservoir for anthropogenic radionuclide fallout. Newly bare surfaces resulting from grassland degradation over the dust source area could generate abrupt increases in the concentration of anthropogenic radionuclides in the air, despite the fact that nuclear testing or accidents have not occurred.

\section{A2 Other source of ${ }^{137} \mathrm{Cs}$ in the atmosphere than soil dust}

${ }^{137} \mathrm{Cs}$ is semi-volatile in fire and spreads with smoke. Fires in the forests polluted by the Chernobyl accident and fuel consumption of the contaminated woods are considered as sources of ${ }^{137} \mathrm{Cs}$ in the air (Igarashi, 2009a). Although the effect is significant in the neighboring and source areas of the polluted boreal forests, such as in eastern and northern Europe (Igarashi, 2009a; Lujaniené et al., 2009; Bourcier et al., 2010), it would be insignificant in East Asia, except in the case of a specific transport event such as the one that occurred in the spring of 2003 (Kaneyasu et al., 2007; Jeong et al., 2008). Consequently, this effect is negligible in East Asia and was not considered in this study.

\section{A3 Effect of Cs isotopes from the Fukushima nuclear accident}

Since 11 March 2011, the accident at the Fukushima Daiichi nuclear power plant has dispersed an abundant amount of radio-Cs as well as other anthropogenic radionuclides to the environment (IRSN, 2011). The environmental radioactivity level increased several orders of magnitude from previous levels. The levels of anthropogenic radionuclides con-

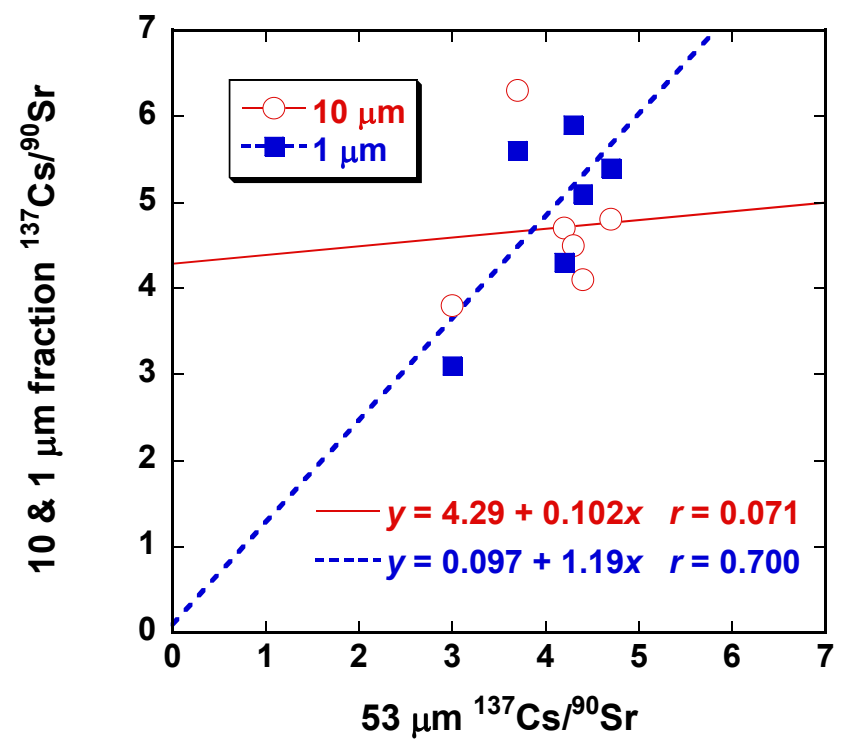

Fig. B1. Correlations of the ${ }^{137} \mathrm{Cs} /{ }^{90} \mathrm{Sr}$ activity ratio in the silt (10$\mu \mathrm{m})$ and clay-silt $(1-\mu \mathrm{m})$ fractions of the Mongolian surface soil samples with the $53-\mu \mathrm{m}$ fraction from the same sample.

veyed by Asian dust are far below those of Fukushima, especially in eastern and northern Japan. Local resuspension of the Fukushima radioactivity will control the level of atmospheric deposition for the time being in Japan.

\section{Appendix B}

\section{Grain-size effect on ${ }^{137} \mathrm{Cs} /{ }^{90} \mathrm{Sr}$ - a preliminary test}

As discussed in the Sect. 3.4, it is necessary to extract and analyze fine particles with a diameter of a few micrometers, which is the size of the long-range transported fraction of dust particles, to understand the effect of grain size on the ${ }^{137} \mathrm{Cs} /{ }^{90} \mathrm{Sr}$ activity ratio in surface soil. Accordingly, we prepared a pneumatic type of separator using cyclones and determined the size-separated fractions of the soil samples for the ${ }^{137} \mathrm{Cs} /{ }^{90} \mathrm{Sr}$ ratio. The results for 6 Mongolian soil samples are shown in Fig. B1. The 10- $\mu \mathrm{m}$ size fraction (the silt fraction) had a mode diameter of 10 to $20 \mu \mathrm{m}$, and the $1-\mu \mathrm{m}$ fraction (the clay-silt fraction) had a mode diameter of 3 to $6 \mu \mathrm{m}$ as determined by a Coulter counter and a laser diffraction apparatus (more detailed methods and results will be published elsewhere). Data from the $10-\mu \mathrm{m}$ fraction were not correlated with those from the 53- $\mu \mathrm{m}$ fraction, whereas those from the $1-\mu \mathrm{m}$ fraction were correlated. Although the number of the samples analyzed is small and we have no good explanation yet for the results, the clay-silt-sized dust particles may have a similar ${ }^{137} \mathrm{Cs} /{ }^{90} \mathrm{Sr}$ ratio as the $53-\mu \mathrm{m}$ fraction.

Acknowledgements. The authors thank the Mongolian Institute of Meteorology and Hydrology for supporting our survey. Y. Sato, 
formerly at the MRI, is acknowledged for suggesting the international collaboration. The authors thank T. Hashimoto, Japan Chemical Analysis Center, and K. Matsuda and H. Kawamura, Kyushu Environmental Evaluation Association, for helping to plan and support the survey. All samples were exported and imported following all regulations and with the approval of both Mongolian and Japanese authorities. E. Fujiwara, Fuji Staff, is acknowledged for her office work for both the survey and the export/import of the Mongolian soil samples. Sample preparation and radiochemical analyses were carried out by K. Inukai, Y. Togashi, M. Tomita, and T. Mizo, KANSO Co. Ltd. C. Takeda, TNS Co. Ltd., helped with the analysis of the size-separated soil fraction. Part of the expense for conducting the Mongolian survey and the sample analysis was covered by the fund for Radioactivity Survey in Japan from the Ministry of Education, Culture, Sports, Science and Technology. M. Noumi, TEC Planning, helped edit the manuscript. Thanks are also due to K. Tagami, National Institute of Radiological Sciences, for helpful discussion of $K_{\mathrm{d}}$ values of ${ }^{90} \mathrm{Sr}$ and ${ }^{137} \mathrm{Cs}$.

Edited by: P. Jöckel

\section{References}

Akata, N., Hasegawa, H., Kawabata, H., Chikuchi, Y., Sato, T., Ohtsuka, Y., Kondo, K., and Hisamatsu, S.: Deposition of ${ }^{137} \mathrm{Cs}$ in Rokkasho, Japan and its relation to Asian dust, J. Environ. Radioactiv., 95, 1-9, 2007.

Aoyama, M., Hirose, K., and Igarashi, Y.: Re-construction and updating our understanding on the global weapons tests ${ }^{137} \mathrm{Cs}$ fallout, J. Environ. Monit., 8, 431-438, 2006.

Bayasgalan, M.: Drought and its influence on dryness, The thesis presented for the $\mathrm{Ph}$. D. in geography, National University of Mongolia, pp. 120, Ulaanbaatar, 2005.

Bourcier, L., Sellegri, K., Masson, O., Zangrando, R., Barbante, C., Gambaro, A., Pichon, J.-M., Boulon, J., and Laj, P.: Experimental evidence of biomass burning as a source of atmospheric ${ }^{137} \mathrm{Cs}$, puy de Dôme (1465 m a.s.l.), France, Atmos. Environ., 44, 2280-2286, 2010.

Chen, Y.-S., Sheen, P.-C., Chen E.-R., Liu, Y.-K., Wu, T.-N., and Yang, C.-Y.: Effects of Asian dust storm events on daily mortality in Taipei, Taiwan, Environmental Research, 95, 151-155, 2004.

Chen, J., Li, G., Yang, J., Rao, W., Lu, H., Balsam, W., Sun, Y., and $\mathrm{Ji}, \mathrm{J} .: \mathrm{Nd}$ and $\mathrm{Sr}$ isotopic characteristics of Chinese deserts, Implications for the provenances of Asian dust, Geochim. Cosmochim. Acta., 71, 3904-3914, 2007.

Danesi, P. R., Moreno, J., Makarewicz, M., and Louvat, D.: Residual radionuclide concentrations and estimated radiation doses at the former French nuclear weapons test sites in Algeria, Appl. Radiat. Isotopes, 66, 1671-1674, 2008.

Ding, R., Li, J., Wang, S., and Ren, F.: Decadal change of the spring dust storm in northwest China and the associated atmospheric circulation, Geophys. Res. Lett., 32, L02808, doi:10.1029/2004GL021561, 2005.

Forsberg, S. and Strandmark, M.: Migration and chemical availability of ${ }^{137} \mathrm{Cs}$ and ${ }^{90} \mathrm{Sr}$ in Swedish long-term experimental pastures, Water, Air, and Soil Pollution, 127, 157-171, 2001.

Fujiwara, H.: Atmospheric deposition of radioactive cesium $\left({ }^{137} \mathrm{Cs}\right)$ associated with dust events in East Asia, Bull. Natl. Inst.
Agro-Environ. Sci., 27, 85-115, 2010.

Fujiwara, H., Fukuyama, T., Shirato, Y., Ohkuro, T., Taniyama, I., and Zhang, T.-H.: Deposition of atmospheric ${ }^{137} \mathrm{Cs}$ in Japan associated with the Asian dust event of March 2002, Sci. Total. Environ., 384, 306-315, doi:10.1016/j.scitotenv.2007.05.024, 2007.

Fukuyama, T. and Fujiwara, H.: Contribution of Asian dust to atmospheric deposition of radioactive cesium $\left({ }^{137} \mathrm{Cs}\right)$, Sci. Total Environ., 405, 389-395, 2008.

Grousset, F., Ginoux, P., Bory, A., and Biscaye, P.: Case study of a Chinese dust plume reaching the French Alps, Geophys. Res. Lett., 30(6), 1277, doi:10.1029/2002GL016833, 2003.

Han, Y., Fang, X., Kang, S., Wang, H., and Kang, F.: Shifts of dust source regions over central Asia and the Tibetan Plateau: Connections with the Arctic oscillation and the westerly jet, Atmos. Environ., 42, 2358-2368, 2008.

Hara, Y., Uno, I., and Wang, Z.: Long-term variation of Asian dust and related climate factors, Atmos. Environ., 40, 6730-6740, 2006.

Hayasaki, M., Yamamoto, M. K., Higuchi, A., Shimizu, A., Mori, I., Nishikawa, M., and Takasuga, T.: Asian dust transport to Kanto by flow around Japan's central mountains, SOLA, 7A, 032-035, doi:10.2151/sola.7A-009, 2011.

Hirose, K. and Sugimura, Y.: Excess ${ }^{228}$ Th in the airborne dust: an indicator of continental dust from the East Asian deserts, Earth Planet. Sci. Lett., 70, 110-114, 1984.

Hirose, K., Igarashi, Y., Aoyama, M., Kim, C. K., Kim, C. S., and Chang, B. W.: Recent trends of plutonium fallout observed in Japan: plutonium as a proxy for desertification, J. Environ. Monit., 5, 302-307, 2003.

Hirose, K., Igarashi, Y., Aoyama, M., and Inomata, Y.: Depositional behaviors of plutonium and thorium isotopes at Tsukuba and Mt. Haruna in Japan indicate the sources of atmospheric dust, J. Environ. Radioact., 101, 106-112, doi:10.1016/j.jenvrad.2009.09.003, 2010.

Huang, J., Minnis, P., Chen, B., Huang, Z., Liu, Z., Zhao, Q., Yi, Y., and Ayers, J. K.: Long-range transport and vertical structure of Asian dust from CALIPSO and surface measurements during PACDEX, J. Geophys. Res., 113, D23212, doi:10.1029/2008JD010620, 2008.

Ichinose, T., Yoshida, S., Hiyoshi, K., Sadakane, K., Takano, H., Nishikawa, M., Mori, I., Yanagisawa, R., Kawazato, H., Yasuda, A., and Shibamoto, T.: The effects of microbial materials adhered to Asian sand dust on allergic lung inflammation, Environ. Contam. Toxic., 20(1), 48-56, 2005.

Igarashi, Y.: Taiki chuno Busshitsu Junkan Kenkyu to Foruauto, Isotope News, 2004(5), 2-8, 2004 (in Japanese).

Igarashi, Y.: Anthropogenic radioactivity in aerosol - A review focusing on studies during the 2000s, Jpn. Health Phys., 44(3), 313-323, 2009a.

Igarashi, Y.: Houshasei Douitai Bunseki, in: Kosa (New version), edited by: Iwasaka, Y., Nishikawa, M., Yamada, M., and Hong, C.-S., Kokin Shoin, Tokyo. pp. 81-87, 2009b (in Japanese).

Igarashi, Y., Aoyama, M., Hirose, K., Miyao, T., and Yabuki, S.: Is it possible to use ${ }^{90} \mathrm{Sr}$ and ${ }^{137} \mathrm{Cs}$ as tracers for the aeolian transport?, Water Air Soil Poll., 130, 349-350, 2001.

Igarashi, Y., Aoyama, M., Hirose, K., Povinec, P., and Yabuki, S.: What anthropogenic radionuclides $\left({ }^{90} \mathrm{Sr}\right.$ and $\left.{ }^{137} \mathrm{Cs}\right)$ in atmospheric deposition, surface soils and aeolian dusts suggest for 
dust transport over Japan, Water Air Soil Poll. Focus, 5, 51-69, 2005.

Igarashi, Y., Aoyama, M., Hirose, K., and Shinoda, Y.: Temporal and spatial variation in radioactivity deposition in JapanInfluence of the Asian dust-Kosa, Proceedings of the International Symposium on Environmental Modeling and Radioecology, edited by: Hisamatsu, S., Ueda, S., Kakiuchi, H., and Akata, N., Institute of Environmental Sciences, 150-156 pp., 2006.

Igarashi, Y., Inomata, Y., Aoyama, M., Hirose, K., Takahashi, H., Shinoda, Y., Sugimoto, N. Shimizu, A., and Chiba, M.: Possible change in Asian dust source suggested by atmospheric anthropogenic radionuclides during the 2000s, Atmos. Environ. 43, 2971-2980, 2009.

IRSN (Institute de Radioprotection et de Sûreté Nucléaire): IRSN publishes assessment of radioactivity released by the Fukushima Daiichi Nuclear Power Plant (Fukushima I) through 22 March 2011, http://www.irsn.fr/EN/news/Documents/IRSN fukushima-radioactivity-released-assessment-EN.pdf, 2011.

Iwasaka, Y.: Kosa sono Nazo wo Ou, Kinokuniya Shoten, Tokyo, 228 pp., 2006 (in Japanese).

Iwasaka, Y., Minoura, H., and Nagaya, K.: The transport and spacial scale of Asian dust-storm clouds: a case study of the duststorm event of April 1979, Tellus, 358, 189-196, 1983.

Iwasaka, Y., Nishikawa, M., Yamada, M., and Hong, C.-S. (Eds.): Kosa (New version), Kokin Shoin, Tokyo, 342 pp., 2009 (in Japanese).

Jeong, J. I., Park, R. J., and Youn, D.: Effects of Siberian forest fires on air quality in East Asia during May 2003 and its climate implication, Atmos. Environ., 42, 8910-8922, 2008.

Kamei-Ishikawa, N., Uchida, S., and Tagami, K.: Distribution coefficients for ${ }^{85} \mathrm{Sr}$ and ${ }^{137} \mathrm{Cs}$ in Japanese agricultural soils and their correlations with soil properties, J. Radioanal. Nucl. Ch., 277, 433-439, 2008.

Kanayama, S., Yabuki, S., Yanagisawa, F., and Motoyama, R.: The chemical and strontium isotope composition of atmospheric aerosols over Japan: the contribution of long-range-transported Asian dust (Kosa), Atmos. Environ., 36, 5159-5175, 2002.

Kaneyasu, N., Igarashi, Y., Sawa, Y., Takahashi, H., Takada, H., Kumata, H., and Höller, R.: Chemical and optical properties of 2003 Siberian forest fire smoke observed at the summit of Mt. Fuji, Japan, J. Geophys. Res., 112, D13214, doi:10.1029/2007JD008544, 2007.

Kim, J.: Transport routes and source regions of Asian dust observed in Korea during the past 40 years (1965-2004), Atmos. Environ., 42, 4778-4789, 2008.

Kurosaki, Y. and Mikami, M.: Recent frequent dust events and their relation to surface wind in East Asia, Geophys. Res. Lett., 30, 1736, doi:10.1029/2003GL017261, 2003.

Kurosaki, Y. and Mikami, M.: Regional difference in the characteristic of dust event in east Asia: Relationship among dust outbreak, surface wind, and land surface condition, J. Meteorol. Soc. Jpn., 83A, 1-18, 2005.

Kurosaki, Y. and Mikami, M.: Threshold wind speed for dust emission in east Asia and its seasonal variations, J. Geophys. Res., 112, D17202, doi:10.1029/2006JD007988, 2007.

Kwon, H.-J., Cho, S.-H., Chun, Y., Lagarde, F., and Pershagen, G.: Effects of the Asian dust events on daily mortality in Seoul, Korea, Environ. Res., Section A, 90, 1-5, doi:10.1006/enrs.2002.4377, 2002.
Lee, M. K., Lee, Y. I., and Yi, H.-I.: Provenances of atmospheric dust over Korea from $\mathrm{Sr}-\mathrm{Nd}$ isotopes and rare earth elements in early 2006, Atmos. Environ., 44, 2401-2414, 2010.

Li, G., Chen, J., Ji, J., Yang, J., and Conway, T. M.: Natural and anthropogenic sources of East Asian dust, Geology, 37, 727-730, doi:10.1130/G30031A.1, 2009.

Li, J., Cook, E. R., Chen, F., Davi, N., D’Arrigo, R., Gou, X., Wright, W. E., Fang, K., Jin, L., Shi, J., and Yang, T.: Summer monsoon moisture variability over China and Mongolia during the past four centuries, Geophys. Res. Lett., 36, L22705, doi:10.1029/2009GL041162, 2009.

Lim, J.-Y. and Chun, Y.: The characteristics of Asian dust events in Northeast Asia during the springtime from 1993 to 2004, Global Planet. Change, 52, 231-247, 2006.

Lin, M.-L., Chu, C.-M., Shih, J.-Y., Wang, Q.-B., Chen, C.-W., Wang, S., Tao, Y.-H., and Lee, Y.-T.: Assessment and monitoring of desertification using satellite imagery of MODIS in East Asia, Proc. of SPIE, 6411, 641123, 2006

Liu, J., Qi, Y., Shi, H., Zhuang, D., and Hu, Y.: Estimation of wind erosion rates by using ${ }^{137} \mathrm{Cs}$ tracing technique: A case study in Tariat-Xilin Gol transect, Mongolian Plateau, Chinese Science Bulletin, 53(5), 751-758, doi:10.1007/s11434-008-0007-0, 2008.

Lujaniené, G., AninkeViius, V., and Lujanas, V.: Artificial radionuclides in the atmosphere over Lithuania, J. Environ. Radioactiv., 100, 108-119, 2009.

Maher, B. A., Prospero, J. M., Mackie, D., Gaiero, D., Hesse, P. P., and Balkanski, Y.: Global connections between aeolian dust, climate and ocean biogeochemistry at the present day and at the last glacial maximum, Earth-Sci. Rev., 99, 61-97, 2010.

Masson, O., Piga, D., Gurriaran, R., and D'Amico, D.: Impact of an exceptional Saharan dust outbreak in France: $\mathrm{PM}_{10}$ and artificial radionuclides concentrations in air and in dust deposit, Atmos. Environ., 44, 2478-2486, doi:10.1016/j.atmosenv.2010.03.004, 2010.

Menut, L., Masson, O., and Bessagnet, B.: Contribution of Saharan dust on radionuclide aerosol activity levels in Europe?, The 2122 February 2004 case study, J. Geophys. Res., 114, D16202, doi:10.1029/2009JD011767, 2009.

Mikami, M.: Fusou Dasuto no Taikichu heno Kyoukyu-ryo Hyouka to Kikou heno Eikyou nikansuru Nichu Kyoudou Kenkyu (ADEC), Tenki, 54, 142-150, 2007 (in Japanese).

Mikami, M., Shi, G. Y., Uno, I., Yabuki, S., Iwasaka, Y., Yasui, M., Aoki, T., Tanaka, T. Y., Kurosaki, Y., Masuda, K., Uchiyama, A., Matsuki, A., Sakai, T., Takemi, T., Nakawo, M, Seino, N., Ishizuka, M., Satake, S., Fujita, K., Hara, Y., Kai, K., Kanayama, S., Hayashi, M., Du, M., Kanai, Y., Yamada, Y., Zhang, X. Y., Shen, Z., Zhou, H., Abe, O., Nagai, T., Tsutsumi, Y., Chiba, M., and Suzuki, J.: Aeolian dust experiment on climate impact, An overview of Japan-China joint project ADEC, Global Planet. Change, 52, 142-172, 2006.

Miller, J. R. and Reittemeier, R. F.: The leaching of radiostrontium and radiocesium through soils, Soil Sci. Soc. Proceedings, 141144, 1963.

Miller, R. L., Tegen, I., and Perlwitz, J.: Surface radioactive forcing by soil dust aerosols and the hydrologic cycle, J. Geophys. Res., 109, D04203, doi:10.1029/2003JD004085, 2004.

Mongolia: Assessment Report on Climate Change 2009 (MARCC2009), Lead Authors: Dagvadorj, D., Natsagdorj, L., 
Dorjpurev, J., Namkhainyam, B., Contributing Authors: Gomboluudev, P., Batimaa, P., Jugder, D., Davaa, G., Erdenetsetseg, B., Bayarbaatar, L., Tuvaansuren, T., Ulziisaikhan, V., Bolortsetseg, B., Bayasgalan, Sh., Ganbaatar, T., Khudulmur, S., Ministry of Nature, Environment and Tourism, Mongolia, Supported by UNEP, UNDP, Ulaanbaatar, ISBN 978-99929-934-3-X, 2010.

Nagashima, K., Tada, R., Tani, A., Toyoda, S., Sun, Y., and Isozaki, Y.: Contribution of aeolian dust in Japan Sea sediments estimated from ESR signal intensity and crystallinity of quartz, Geochem. Geophys. Geosyst., 8, Q02Q04, doi:10.1029/2006GC001364, 2007.

Nagashima, K., Nishido, H., Kayama, M., Toyoda, S., Igarashi, Y., and Tada, R.: Provenance study of Asian dust based on cathodoluminescence analysis of single quartz grain, Japan Geoscience Union Meeting 2010 (23-28 May 2010, Makuhari, Chiba Japan), 2010.

Nakai, S., Halliday, A. N., and Rea, D. K.: Provenance of dust in the Pacific Ocean, Earth Planet. Sci. Lett., 119, 143-157, 1993.

Nakano, T., Yokoo, Y., Nishikawa, M., and Koyanagi, H.: Regional $\mathrm{Sr}-\mathrm{Nd}$ isotopic ratios of soil minerals in northern China as Asian dust fingerprints, Atmos. Environ., 38, 3061-3067, 2004.

Narabayar, P.: Mongoru no Kansou Chiiki, in: Kosa (New version), edited by: Iwasaka, Y., Nishikawa, M., Yamada, M., and Hong, C.-S., Kokin Shoin, Tokyo. 26-30 pp., 2009 (in Japanese).

Ono, Y., Naruse, T., Ikeya, M., Kohno, H., and Toyoda, S.: Origin and derived courses of eolian dust quartz deposited during marine isotope stage 2 in East Asia, suggested by ESR signal intensity, Global Planet. Change, 18, 129-135, 1998.

Osada, K.: Kosa (Asian dust), Tenki, 54, 697-700, 2007 (in Japanese).

Otsuji-Hatori, M., Igarashi, Y., and Hirose, K.: Preparation of a reference fallout material for activity measurements, J. Environ. Radioactiv., 31, 143-155, 1996.

Qian, W., Quan, L., and Shi, S.: Variations of the dust storm in China and its climatic control, J. Climate, 15, 1216-1229, 2002.

Ritchie, J. C. and McHenry, J. R.: Application of radioactive fallout cesium-137 for measuring soil erosion and sediment accumulation rates and patterns: A review, J. Environ. Qual., 19, 215-233, 1990.

Sassen, K., DeMott, P. J., Prospero, J. M., and Poellot, M. R.: Saharan dust storms and indirect aerosol effects on clouds: CRYSTAL-FACE results, Geophys. Res. Lett., 30(12), 1633, doi:10.1029/2003GL017371, 2003.

Shao, Y. and Dong, C. H.: A review on East Asian dust storm climate, modeling and monitoring, Global Planet. Change, 52, 122, 2006.

Sugimoto, N., Hara, Y., Yumimoto, K., Uno, I., Nishikawa, M., and Dulam, J.: Dust emission estimated with an assimilated dust transport model using lidar network data and vegetation growth in the Gobi Desert in Mongolia, SOLA, 6, 125-128, doi:10.2151/sola.2010-032, 2010.
Sun, J., Zhang, M., and Liu, T.: Spatial and temporal characteristics of dust storms in China and its surrounding regions, 19601999: Relations to source area and climate, J. Geophys. Res., 106(D10), 10325-10333, 2001.

Sun, Y., Tada, R., Chen, J., Chen, H., Toyoda, S., Tani, A., Isozaki, Y., Nagashima, K., Hasegawa, H., and Ji, J.: Distinguishing the sources of Asian dust based on electron spin resonance signal intensity and crystallinity of quartz, Atmos. Environ., 41(38), 8537-8548, 2007.

Tamamura, S., Sato, T., Ota, Y., Wang, X., Tang, N., and Hayakawa, K.: Long-range transport of polycyclic aromatic hydrocarbons (PAHs) from the eastern Asian continent to Kanazawa, Japan with Asian dust, Atmos. Environ., 41, 2580-2593, 2007.

Tanaka, T.-Y. and Chiba, M.: A numerical study of the contributions of dust source regions to the global dust budget, Global Planet. Change, 52, 88-104, 2006.

Tegen, I. and Schepanski, K.: The global distribution of mineral dust, IOP Conf. Series: Earth and Environmental Science, 7, 012001, doi:10.1088/1755-1307/7/1/012001, 2009.

Tian, S.-F., Inoue, M., and Du, M.: Influence of dust storm frequency in northern China on fluctuations of Asian dust frequency observed in Japan, SOLA, 3, 121-124, doi:10.2151/sola.2007031, 2007.

Tsukada, H. Takeda, A., Hisamatsu, S., and Inaba, J.: Concentration and specific activity of fallout ${ }^{137} \mathrm{Cs}$ in extracted and particle-size fractions of cultivated soils, J. Environ. Radioactiv., 99, 875-881, 2008.

Wang, X., Chen, F., and Dong, Z.: The relative role of climatic and human factors in desertification in semiarid China, Global Environ. Change, 16, 48-57, 2006.

Wang, X., Huan, J., Ji, M., and Higuchi, K.: Variability of East Asia dust events and their long-term trend, Atmos. Environ., 42, 3156-3165, 2008.

World Meteorological Organization, Manual on Codes International Codes Volume I.1 (Annex II to WMO Technical Regulations) Part A - Alphanumeric Codes, WMO-No. 306, 2009 edition, Geneva, Switzerland, 2009.

Xuan, J., Sokolik, I. N., Hao, J., Guo, F., Mao, H., and Yang, G.: Identification and characterization of sources of atmospheric mineral dust in East Asia, Atmos. Environ., 38, 6239-6252, 2004.

Yu, R., Wang, B., and Zhou, T.: Tropospheric cooling and summer monsoon weakening trend over East Asia, Geophys. Res. Lett., 31, L22212, doi:10.1029/2004GL021270, 2004.

Yuan, Y. and Li, J.: The wet-dry changes in recent 40 years in Taklimakan area, Chinese Geographical Science., 9(1), 57-62, 1999.

Zhang, X. Y., Gong, S. L., Zhao, T. L., Arimoto, R., Wang, Y. Q., and Zhou, Z. J.: Sources of Asian dust and role of climate change versus desertification in Asian dust emission, Geophys. Res. Lett., 30(24), 2272, doi:10.1029/2003GL018206, 2003.

Zou, X. K. and Zhai, P. M.: Relationship between vegetation coverage and spring dust storms over northern China, J. Geophys. Res., 109, D03104, doi:10.1029/2003JD003913, 2004. 